\title{
STATUS OF NUTRIENT ELEMENTS IN RICE GRAIN IN RELATION TO SILICON ACCUMULATION PATTERN DURING GRAIN FILLING
}

\author{
Tahmid Hossain Ansari ${ }^{1}$, Kozo Iwasaki ${ }^{2}$, Tetsushi Yoshida ${ }^{2}$, Yoshinori Yamamoto ${ }^{2}$ and Akira \\ Miyazaki $^{2}$ \\ Bangladesh Rice Research Institute, Gazipur 1701, Bangladesh. \\ ${ }^{2}$ Faculty of Agriculture, Kochi University, Japan 783-8502 \\ *Corresponding author: tahmidhansari@yahoo.com
}

Key words: Rice cultivar, rice hull, brown rice, grain filling, silicon, nutrient elements

\begin{abstract}
Rice varieties Tadukan (indica), Nanjing 11(indica), Nipponbare (japonica) and Arborio (javanica) were tested to find out the content and accumulation pattern of $\mathrm{Si}$ in the hull and brown rice during the grain filling periodand the changes in the weight or the contents of $\mathrm{N}, \mathrm{P}, \mathrm{K}, \mathrm{Ca}$ and $\mathrm{Mg}$ both in the hull and brown rice. The largest increment in the hull weight during heading to maturity was observed for Arborio. The content of $\mathrm{Si}$ in the hull and brown rice increased gradually until 30 days after heading. At maturity, the amount of $\mathrm{Si}$ in the brown rice was one twentieth of the hull, irrespective of the cultivars. During the GFP, the increment of $\mathrm{Si}$ content was highest in Arborio among the cultivars, and the increase of $\mathrm{Si}$ content in the hull of was more remarkable than that of $\mathrm{Si}$ concentration. Furthermore, $\mathrm{Si}$ concentration in the hull of Tadukan was comparable to Arborio, despite the low $\mathrm{Si}$ content. These results suggested that the high amount of $\mathrm{Si}$ in the hull of Arborio was accomplished by the high number of silica cells on the large grain surface rather than the increased deposition of $\mathrm{Si}$ in each silica cell. Both the content and concentration of $\mathrm{N}$ and $\mathrm{P}$ in the hull decreased until maturity and twas negatively related to the accumulation of $\mathrm{Si}$ in the hull. In brown rice, the content of these elements increased with time although the changes in concentrations were slight andmost pronounced in Arborio. Therefore, it was supposed that the heavy accumulation of $\mathrm{Si}$ in the hull was the cause of enhanced accumulation of other elements in the brown rice. In addition, observation of $\mathrm{Si}$ distribution on the abaxial surface of lemma by electron-probe $\mathrm{X}$-ray microanalysis revealed heavy deposition of $\mathrm{Si}$ on the dentate protuberances of the hull, which was supposed to be one of the reasons for different hull weight among the cultivars.
\end{abstract}

\section{Introduction}

Silicon ( $\mathrm{Si}$ ) has been recognized as an agronomical essential element for increasing and/or sustaining the rice production (Takahashi et al., 1990; Epstein, 1994; Savant et al., 1997; Hassanuzzaman et al., 2014). Adequate supply of $\mathrm{Si}$ has been reported to induce resistance/tolerance in the rice plant to biotic and abiotic stress (Okuda and Takahashi, 1965; Yamauchi and Winslaw, 1987; Hossain et al., 1999; Ma, 2004; $\mathrm{Ma}$ and Yamaji, 2006; Hassanuzzaman et al., 2014). Also, several researchers have shown the improvement of physiological characteristics and increase of dry matter production by $\mathrm{Si}$ application in rice (Ma et al., 1989; Liang et al., 1994).

At the reproductive growth stage, $\mathrm{Si}$ can increase the number of spikelets on the secondary branch, the ripening percentage, and the weight of grains (Seo and Ota, 1983; Nhan et al., 2012). Mizuno (1987) reported that the hulls of poor quality milky-white grains are generally low in $\mathrm{Si}$ content, which is directly proportional to the $\mathrm{Si}$ content in the straw. According to Inanaga et al. (2002), $\mathrm{Si}$ may positively 
Ansai et al.

affect the cell division and formation of cell walls in the spikelet before heading. These studies indicate that $\mathrm{Si}$ plays an important role in hull formation which in turn influences grain quality.

Besides the above mentioned physiological importance, $\mathrm{Si}$ in the rice hull has been attracting the attention as an environmentally friendly soil amendment. Since large amounts of $\mathrm{Si}$ absorbed by the rice plants are deposited as amorphous $\mathrm{SiO}_{2}$ mainly in the leaves and hulls, their utilization as soil amendments is effective for plant $\mathrm{Si}$ recycling (Hashim et al., 1996; Savant et al., 1997). Therefore, the determination of $\mathrm{Si}$ concentrations in the hulls of various rice cultivars would give valuable information for the utilization of rice hulls.

Silicon regulation on other mineral nutrient uptake indicated that $\mathrm{Si}$ fertilization made soil phophorus (P) more available, potassium (K) uptake improved and a better absorption of nitrogen $(\mathrm{N})$ and calcium $(\mathrm{Ca})$ to plants (Eneji et al., 2008; Mali and Aiery, 2008a, 2008b). In this study, the content and accumulation pattern of $\mathrm{Si}$ in the hulls and brown rice during the grain filling period of several cultivars, and compared their relations to the changes in the weight and in the contents of other mineral elements in the hulls and brown rice. Furthermore, the differences in morphological structure and $\mathrm{Si}$ distribution on the abaxial surface of the rice hull of different cultivars were examined by electron-probe X-ray microanalysis.

\section{Materials and Methods}

\section{Plant material and sampling}

A field experiment was conducted in 2001 at a paddy field of grey lowland soil (Typic Endoaquepts) in Faculty of Agriculture, Kochi University, Japan. The surface soil $(0-15 \mathrm{~cm})$ with characteristics of $\mathrm{pH}\left(\mathrm{H}_{2} \mathrm{O}, 1: 2.5 \mathrm{w} / \mathrm{v}\right), 5.40 ; \mathrm{EC}, 0.072 \mathrm{dS} \mathrm{m}^{-1}$; total $\mathrm{N}, 1.17 \mathrm{~g} \mathrm{~kg}^{-1}$; total $\mathrm{C}, 12.7 \mathrm{~g} \mathrm{~kg}^{-1}$; exchangeable cations $\mathrm{Ca}, 2.87 \mathrm{cmol}_{\mathrm{c} \mathrm{kg}} \mathrm{k}^{-1}$; $\mathrm{Mg}, \quad 0.38 \mathrm{cmol}_{\mathrm{c}} \mathrm{kg}^{-1} ; \mathrm{K}, 0.26 \mathrm{cmol}_{\mathrm{c}} \mathrm{kg}^{-1}$; and CEC, $7.67 \mathrm{cmol}_{\mathrm{c}} \mathrm{kg}^{-1}$. Basal fertilizer was supplied at the rate of $100 \mathrm{~kg} \mathrm{~N}, 100 \mathrm{~kg} \mathrm{P} \mathrm{O}_{5}$, and $100 \mathrm{~kg} \mathrm{~K}_{2} \mathrm{O} \mathrm{ha}^{-1}$ by using a coated slow release fertilizer (E-80, 140 d-type, Kumiai, Co. Ltd.). Using $\mathrm{NH}_{4} \mathrm{Cl}$, additional $20 \mathrm{~kg} \mathrm{~N}$ ha $^{-1}$ was also applied with the slow release fertilizer. Silicate fertilizers were not incorporated in the field throughout the cultivation.

Four rice (Oryza sativa L.) cultivars Tadukan (indica), Nanjing 11 (indica), Nipponbare (japonica), and Arborio (javanica) were selected. Grain characteristics of the above mentioned cultivars are shown in Table 1. Two seedlings of 19 days old of each cultivar per hill were transplanted with spacing was $30 \mathrm{~cm}$ Y $15 \mathrm{~cm}$. Other cultural conditions were conventional ones. Plots of each cultivar were arranged following the randomized block design with two replications.

Table I. Characteristics of grains of different cultivars.

\begin{tabular}{|c|c|c|c|c|c|c|}
\hline \multirow[t]{2}{*}{ Cultivar } & \multirow{2}{*}{$\begin{array}{c}\text { Ecospecies/ } \\
\text { type }\end{array}$} & \multirow[t]{2}{*}{ Grain size } & Length & Width & Thickness & Volume \\
\hline & & & & \multicolumn{3}{|l|}{$(\mathrm{mm})$} \\
\hline Tadukan & Indica & Small & $\begin{array}{l}11.79 \mathrm{c} \\
10.43\end{array}$ & $\begin{array}{l}2.64 \text { a } \\
3.87\end{array}$ & $1.87 \mathrm{a}$ & $24.73 \mathrm{a}$ \\
\hline Nanjing 11 & Indica & Medium & $\mathrm{b}$ & $\mathrm{b}$ & $2.39 \mathrm{~b}$ & $30.46 c$ \\
\hline Nipponbare & Japonica & Medium & $\begin{array}{r}9.05 \mathrm{a} \\
12.28\end{array}$ & $\begin{array}{l}4.13 \mathrm{C} \\
4.87\end{array}$ & $2.47 \mathrm{~b}$ & $28.20 \mathrm{~b}$ \\
\hline Arborio & Javanica & Large & $\mathrm{d}$ & $\mathrm{d}$ & $2.58 \mathrm{c}$ & $47.08 \mathrm{~d}$ \\
\hline
\end{tabular}

All the means for each parameter are average of 50 seeds. 
Status of Nutrient Elements in Rice Grain in Relation to Silicon Accumulation Pattern During

Grain Filling

Means in a column do not differ significantly for the same letter by DMRT at 5\%. Measurement of seeds was done by vedio micrometer (VM-30, Olympus Co. Ltd.).

Ten panicles of equal size were collected from different spots in each plot at heading, 10 days after heading (DAH), $20 \mathrm{DAH}, 30 \mathrm{DAH}$ and at maturity. All of the grains from panicles in each plot were mixed and composite samples were obtained. All of the spotted, distorted or abnormal seeds were discarded from the samples. In every composite sample, each grain was separated into a hull and a brown rice, and their dry weights were recorded.

The contents of $\mathrm{Si}$ and other mineral elements in the samples were determined by using an inductively coupled plasma atomic spectrometry (ICP-AES, Shimadzu ICPS 1000IV) after fusion with lithium metaborate (Goto and Ninaki, 1991), unless otherwise stated. Potassium and $\mathrm{Mg}$ were determined by using atomic absorption spectrometer (Shimadzu AA-610S), and $\mathrm{N}$ was determined according to the Kjeldhal method.

\section{Electron probe X-ray microanalysis (EPMA) of lemma}

Inflorescence bract lemma and palea was dissected from the mature seeds at maturity. Lemma was then cut along the length. Prepared lemma was fixed to aluminum disks with adhesive and was coated with a carbon layer approximately $30 \mathrm{~nm}$ thick using a vacuum evaporator (JEOL, JEE-400). Analysis was carried out using a wavelength dispersive type electron probe X-ray microanalyzer (JEOL, JXA-8600MX). The analysis of $\mathrm{Si}$ on the abaxial surface around the tip area of the hull were conducted at an accelerating voltage of $15 \mathrm{kV}$, a sample current of $5 \sim 10^{-8} \mathrm{~A}$, and with a beam diameter of $5 \square \mathrm{Km}$. The X-ray spectrometer was peaked for the first order silicon $\mathrm{K} \square \square$ line $(0.7126 \mathrm{~nm})$, using a thallium acid phthalate (TAP) diffracting crystal. The detection of $\mathrm{Si}$ was performed by X-ray distribution mapping with stage scanning mode. Morphological observation was performed using the secondary electron scanning microscope (SEM) image at a sample current of $2 \sim 10^{-9} \mathrm{~A}$.

Least significant difference (LSD) for the comparison of any pair of the data were analysed.

\section{Results and Discussion}

\section{Dry weights of hull and brown rice}

Among four cultivars, the largest increase in the hull weight was observed for Arborio and the increment was $2.5 \mathrm{mg}$, while the increases in other three cultivars were less than $1.5 \mathrm{mg}$ (Fig. 1). At the same sampling time, the hull weight was maximum in Arborio, followed by Nanjing 11, Nipponbare and Tadukan. The difference of the hull weight between Arborio and Nanjing 11 was larger than the other three cultivars.

From $10 \mathrm{DAH}$ to the maturity, the weight of the brown rice of Arborio increased from 7.5 to $35 \mathrm{mg}$, which was the largest increase among four cultivars, while the increment in the weight of the brown rice of other three cultivars was less than 15 mg (Fig. 1B). At every sampling time, the maximum dry weight among the cultivars was observed for Arborio, followed by Nipponbare, Nanjing 11, and Tadukan, except for the sampling at $10 \mathrm{DAH}$ but no significant difference was observed among four cultivars. Due to the significant weight increase in the brown rice of Arborio during the late stage of the grain filling period, the difference in the weight of the brown rice between Arborio and the other three cultivars was remarkable especially at 30 
Ansai et al.

$\mathrm{DAH}$ and at maturity.

Contents and concentrations of $\mathrm{Si}$ and other elements in hull

The lowest content of $\mathrm{Si}$ per hull was found at heading in all the cultivars (Fig. 2). The content increased gradually up to $30 \mathrm{DAH}$ and then remained almost no change. This tendency was most remarkable for Arborio which accumulated $0.35 \mathrm{mg}$ of $\mathrm{Si}$ in the hull during the period from heading to $30 \mathrm{DAH}$, while other three cultivars accumulated less than $0.20 \mathrm{mg} \mathrm{Si}$. As a result, $\mathrm{Si}$ content per hull at every sampling time was highest in Arborio and no significant difference was found among the other three cultivars. On the other hand, $\mathrm{Si}$ concentrations in the hulls of Nanjing 11 and Nipponbare increased significantly from heading to $20 \mathrm{DAH}$ and those of Tadukan and Arborio continued significant increasing until 30 DAH (Table 2). Different from the $\mathrm{Si}$ content per hull, the remarkable difference in $\mathrm{Si}$ concentration between Arborio and the other three cultivars was not observed, although the $\mathrm{Si}$ concentrations of Tadukan and Arborio were higher than those of Nanjing 11 and Nipponbare at every sampling time.

Table 2. Concentrations of $\mathrm{Si}$ and other elements in the hulls during the grain filling period.

\begin{tabular}{|c|c|c|c|c|c|c|}
\hline \multirow[t]{2}{*}{ Element } & Cultivar & Heading & $10 \mathrm{DAH}$ & $20 \mathrm{DAH}$ & $30 \mathrm{DAH}$ & Maturity \\
\hline & \multicolumn{6}{|c|}{$\mathrm{g} / \mathrm{kg}$ dry weight } \\
\hline \multirow[t]{4}{*}{$\mathrm{Si}$} & Tadukan & 29.94 & 47.91 & 62.04 & 73.74 & 72.71 \\
\hline & Nanjing 11 & 23.81 & 44.27 & 51.98 & 54.48 & 62.58 \\
\hline & Nipponbare & 25.33 & 37.73 & 52.38 & 59.55 & 62.68 \\
\hline & Arborio & 33.88 & 53.66 & 65.69 & 77.64 & 71.57 \\
\hline \multicolumn{2}{|l|}{$\operatorname{LSD}(0.05)$} & & & 7.65 & & \\
\hline \multirow[t]{4}{*}{$\mathrm{N}$} & Tadukan & 11.3 & 6.99 & 5.02 & 4.18 & 3.99 \\
\hline & Nanjing 11 & 9.93 & 5.21 & 4.64 & 3.5 & 3.26 \\
\hline & Nipponbare & 9.74 & 5.94 & 4.32 & 3.76 & 3.49 \\
\hline & Arborio & 11.31 & 7.29 & 5.471 & 4.4 & 4.04 \\
\hline \multicolumn{2}{|c|}{$\mathrm{LSD}(0.05)$} & & & 0.96 & & \\
\hline \multirow[t]{4}{*}{$\mathrm{P}$} & Tadukan & 1.65 & 1.00 & 0.68 & 0.43 & 0.25 \\
\hline & Nanjing 11 & 1.66 & 0.85 & 0.6 & 0.36 & 0.23 \\
\hline & Nipponbare & 1.34 & 0.87 & 0.45 & 0.26 & 0.14 \\
\hline & Arborio & 1.8 & 1.08 & 0.78 & 0.63 & 0.28 \\
\hline \multicolumn{2}{|l|}{$\mathrm{LSD}(0.0 \mathrm{~s})$} & & & 0.11 & & \\
\hline \multirow[t]{4}{*}{$\mathrm{K}$} & Tadukan & 6.85 & 6.97 & 5.04 & 2.7 & 1.14 \\
\hline & Nanjing 11 & 6.64 & 5.29 & 5.22 & 5.0 & 2.4 \\
\hline & Nipponbare & 5.3 & 5.67 & 9.77 & 4.7 & 3.72 \\
\hline & Arborio & 8.95 & 7.03 & 7.48 & 6.19 & 4.72 \\
\hline \multicolumn{2}{|l|}{$\mathrm{LSD}(0.0 \mathrm{~s})$} & & & 1.42 & & \\
\hline \multirow[t]{4}{*}{$\mathrm{Ca}$} & Tadukan & 1.37 & 1.4 & 1.48 & 1.6 & 1.01 \\
\hline & Nanjing 11 & 1.19 & 1.39 & 1.41 & 1.37 & 1.45 \\
\hline & Nipponbare & 1.11 & 0.88 & 1.08 & 1.43 & 1.16 \\
\hline & Arborio & 1.95 & 2.04 & 2.16 & 2.2 & 1.72 \\
\hline \multicolumn{2}{|l|}{$\mathrm{LSD}(0.0 \mathrm{~s})$} & & & 1.42 & & \\
\hline \multirow[t]{3}{*}{$\mathrm{Mg}$} & Tadukan & 1.02 & 0.88 & 0.79 & 0.65 & 0.62 \\
\hline & Nanjing 11 & 1.09 & 0.75 & 0.62 & 0.45 & 0.46 \\
\hline & Nipponbare & 0.84 & 0.59 & 0.29 & 0.22 & 0.23 \\
\hline
\end{tabular}


Status of Nutrient Elements in Rice Grain in Relation to Silicon Accumulation Pattern During

Grain Filling

\begin{tabular}{lllllll} 
& Arborio & 1.2 & 0.91 & 0.71 & 0.59 & 0.52 \\
\hline $\operatorname{LSD}(0.0 \mathrm{~s})$ & & & & 0.11 & & \\
\hline
\end{tabular}

Contrary to the accumulation pattern of $\mathrm{Si}$, the contents and the concentrations of $\mathrm{N}$ and $\mathrm{P}$ in the hull were highest at heading and gradually decreased until maturity in all of the cultivars (Fig. 2 and Table 2). The drastic decreases in the contents of these elements were observed for Arborio and Nanjin 11 within 10 DAH. From heading to maturity, the largest decrease in the content of $\mathrm{N}$ and $\mathrm{P}$ was recorded for Arborio, followed by Nanjin 11. Although the contents and the concentrations of $\mathrm{Mg}$ and $\mathrm{K}$ decreased in the same tendency with $\mathrm{N}$ and $\mathrm{P}$, those of $\mathrm{Mg}$ showed almost no change after $30 \mathrm{DAH}$. In the case of $\mathrm{K}$, the decrease was found clearly only during the late stage of grain filling period. The content and the concentration of $\mathrm{Ca}$ increased until $30 \mathrm{DAH}$ and then decreased, except for Nanjin 11 where they continued increasing gradually until maturity. The increase in the Ca content until 30 $\mathrm{DAH}$ was more pronounced in Arborio than in the other three cultivars. On the other hand, the contents of the examined elements were always highest in Arborio at the same sampling time, and no clear difference was observed among other three cultivars, except for the $\mathrm{Mg}$ content of Nipponbare which was significantly lower than the other cultivars after $20 \mathrm{DAH}$. The concentrations of the examined elements were also highest in Arborio except for $\mathrm{Mg}$ concentrations after $20 \mathrm{DAH}$. However, except for $\mathrm{Ca}$, the differences in the concentrations between Arborio and the other three cultivars were not so large compared with those in their contents.

\section{Contents and concentrations of $\mathrm{Si}$ and other elements in brown rice}

The lowest content of $\mathrm{Si}$ per brown rice was found at heading and it increased gradually until maturity in all the cultivars (Fig. 3). This tendency was most remarkable for Arborio which accumulated $0.02 \mathrm{mg}$ of $\mathrm{Si}$ in the brown rice until maturity, while the other three cultivars accumulated less than $0.005 \mathrm{mg} \mathrm{Si}$. Irrespective of the cultivars, the $\mathrm{Si}$ content in the brown rice at maturity was less than one twentieth of that in the hull. At every sampling time, Si content per brown rice was highest in Arborio and no significant difference was found among the other three cultivars. Different from the $\mathrm{Si}$ content per brown rice, only a slight increase was observed for the $\mathrm{Si}$ concentrations in the brown rice of all the cultivars (Table 3). Further, the remarkable difference in the $\mathrm{Si}$ concentration between Arborio and the other three cultivars was not observed, and Tadukan showed the highest $\mathrm{Si}$ concentration at maturity.

Contrary to the decreasing pattern in the hulls, the contents of $\mathrm{N}, \mathrm{P}, \mathrm{K}, \mathrm{Ca}$, and $\mathrm{Mg}$ in the brown rice were lowest at heading and gradually increased until maturity, except for Nipponbare (Fig. 3 and Table 3). In the case of Nipponbare, slight decreases were observed between $30 \mathrm{DAH}$ and at maturity. From heading to maturity, the largest increase in the content of these elements was recorded for Arborio and the smallest was for Tadukan. The $\mathrm{N}$ concentration in the brown rice was almost in the similar level from $10 \mathrm{DAH}$ to maturity. Although the large fluctuations were not observed for the concentrations of $\mathrm{P}$ and $\mathrm{Mg}$ as well as $\mathrm{N}$, slight increases were found for the $\mathrm{P}$ concentrations between 10 and $20 \mathrm{DAH}$ except for Nipponbare, and for the $\mathrm{Mg}$ concentrations between 20 and $30 \mathrm{DAH}$ of Tadukan and Nipponbare. In the case of $\mathrm{K}$ and $\mathrm{Ca}$, the concentrations decreased steeply between 10 and 20 $\mathrm{DAH}$ and then very slightly until maturity. At the same sampling time, the contents of the examined elements were always highest in Arborio, followed by Nanjing 11 or Nipponbare, and were lowest in Tadukan. However, the differences between Arborio 
Ansai et al.

and the other three cultivars were more remarkable compared with those among the other three cultivars, especially at the late stage of the grain filling period. While the concentrations of $\mathrm{N}, \mathrm{P}$, and $\mathrm{K}$ were also highest in Arborio, those of $\mathrm{Ca}$ and $\mathrm{Mg}$ were highest in Tadukan at every sampling time.

Table 3. Concentrations of $\mathrm{Si}$ and other elements in brown rice during the grain filling period.

\begin{tabular}{|c|c|c|c|c|c|}
\hline \multirow[t]{2}{*}{ Element } & Cultivar & $10 \mathrm{DAH}$ & $20 \mathrm{DAH}$ & $30 \mathrm{DAH}$ & Maturity \\
\hline & \multicolumn{5}{|c|}{$\mathrm{g} / \mathrm{kg}$ dry weight } \\
\hline \multirow[t]{4}{*}{$\mathrm{Si}$} & Tadukan & 0.46 & 0.46 & 0.53 & 0.64 \\
\hline & Nanjing 11 & 0.36 & 0.41 & 0.42 & 0.47 \\
\hline & Nipponbare & 0.33 & 0.32 & 0.38 & 0.57 \\
\hline & Arborio & 0.43 & 0.43 & 0.54 & 0.58 \\
\hline \multicolumn{3}{|l|}{$\mathrm{LSD}(0.05)$} & 0.14 & & \\
\hline \multirow[t]{4}{*}{$\mathrm{N}$} & Tadukan & 13.1 & 14.4 & 14.5 & 14.8 \\
\hline & Nanjing 11 & 13.55 & 14.95 & 15.75 & 14.6 \\
\hline & Nipponbare & 11.75 & 12.25 & 13.2 & 12.7 \\
\hline & Arborio & 16.15 & 16.5 & 17 & 16.55 \\
\hline \multicolumn{3}{|l|}{$\mathrm{LSD}(0.05)$} & 2.06 & & \\
\hline \multirow{4}{*}{$\mathrm{P}$} & Tadukan & 2.77 & 3.2 & 3.39 & 3.42 \\
\hline & Nanjing 11 & 3.1 & 3.73 & 3.83 & 3.79 \\
\hline & Nipponbare & 2.5 & 2.52 & 2.94 & 2.62 \\
\hline & Arborio & 3.39 & 3.86 & 3.95 & 3.87 \\
\hline \multicolumn{3}{|l|}{$\mathrm{LSD}(0.05)$} & 0.39 & & \\
\hline \multirow[t]{4}{*}{$\mathrm{K}$} & Tadukan & 3.99 & 2.92 & 2.97 & 2.83 \\
\hline & Nanjing 11 & 5.05 & 3.92 & 3.77 & 3.41 \\
\hline & Nipponbare & 4.96 & 2.82 & 2.68 & 2.34 \\
\hline & Arborio & 6 & 4.05 & 3.95 & 3.61 \\
\hline \multicolumn{3}{|l|}{$\mathrm{LSD}(0.05)$} & 0.39 & & \\
\hline \multirow[t]{4}{*}{$\mathrm{Ca}$} & Tadukan & 0.3 & 0.23 & 0.22 & 0.22 \\
\hline & Nanjing 11 & 0.26 & 0.21 & 0.2 & 0.19 \\
\hline & Nipponbare & 0.27 & 0.16 & 0.16 & 0.15 \\
\hline & Arborio & 0.26 & 0.17 & 0.17 & 0.15 \\
\hline \multicolumn{3}{|l|}{$\mathrm{LSD}(0.05)$} & 0.04 & & \\
\hline \multirow[t]{4}{*}{ Mg } & Tadukan & 1.19 & 1.19 & 1.38 & 1.45 \\
\hline & Nanjing 11 & 1.55 & 1.53 & 1.59 & 1.63 \\
\hline & Nipponbare & 1.23 & 1.18 & 1.36 & 1.22 \\
\hline & Arborio & 1.43 & 1.39 & 1.43 & 1.33 \\
\hline $\operatorname{LSD}(0.05)$ & & & 0.17 & & \\
\hline
\end{tabular}

Morphological characteristics and $\mathrm{Si}$ distribution on hull

By using SEM, the existence of trichomes and dentate protuberances arranged regularly in rows paralleled with longitudinal axis was confirmed on the outer surface 
Status of Nutrient Elements in Rice Grain in Relation to Silicon Accumulation Pattern During

Grain Filling

around the tip area of the hull for all of the cultivars. The number of trichomes was higher in Arborio and Nanjing 11, followed by Tadukan and Nipponbare (Plate 1). The length of trichomes was longer in Arborio, medium in Nanjing 11 and short in Tadukan. Mapping of $\mathrm{Si}$ on the outer surface of the lemma revealed heavy deposition of $\mathrm{Si}$ on the dentate protuberances on the abaxial surface of hull, and relatively a few amounts of $\mathrm{Si}$ were present in the trichomes.

It is well known that large amounts of $\mathrm{Si}$ absorbed by the rice plants are deposited mainly in the leaves and hulls. Yoshida et al. (1962) estimated the average amounts of $\mathrm{Si}$ in the rice hull and in the leaf sheath as $7.1 \%$ and $4.7 \%$, respectively. The same authors reported that heavy deposition of silicon in the inflorescence bracts/husk especially on the abaxial surface was evident (Yoshida et al. 1962). Furthermore, electron probe microanalysis of lemma and palea of rice has revealed heavy deposition of $\mathrm{Si}$ associated with the abaxial surface (Soni and Parry, 1973; Balasta et al. 1989; Hodson and Sangstar, 1989). Consistent with these previous reports, our study showed that the amount of accumulated $\mathrm{Si}$ was much higher in the hull than in the brown rice irrespective of the cultivars of different grain size and that the accumulation pattern was similar both in the hull and in the brown rice. By the analysis of $\mathrm{Si}$ distribution by EPMA and SEM images, it was also confirmed for all of the cultivars that $\mathrm{Si}$ was heavily deposited on the dentate rectangular protuberances in the abaxial surface of the hull. However, the difference in the amount of the deposited $\mathrm{Si}$ among the cultivars was not found clearly. On the other hand, the higher amount of $\mathrm{Si}$ was detected on the dentate rectangular protuberances than in the trichomes although Soni and Perry (1973) reported that a considerable amount of silicon existed in the trichomes. It seemed necessary to conduct qualitative analysis by EPMA in order to evaluate the amounts of $\mathrm{Si}$ properly.

The results of present study indicated that the $\mathrm{Si}$ content and concentration in the hull of Arborio (javanica type) were significantly higher than those of indicia and japonica type. These different amounts of deposition of $\mathrm{Si}$ on the abaxial surface of the hull among the cultivars were supposed to be one of the reasons for the different weight of hull in each cultivar.

The increase of $\mathrm{Si}$ content in the hull of Arborio during the grain filling period was more remarkable than that of $\mathrm{Si}$ concentration. Furthermore, the $\mathrm{Si}$ concentration of the hull of Tadukan (indica type) was comparable to that of Arborio, despite the low $\mathrm{Si}$ content. Taking into consideration of these facts, the high amount of $\mathrm{Si}$ in the hull of Arborio might be accomplished by the high number of silica cells on the large grain surface rather than the increased deposition of $\mathrm{Si}$ in each silica cell. In addition, SEM image of the hull surface of Arborio revealed the number and the length of the trichome were higher than those of the other cultivars. Most of the absorbed $\mathrm{Si}$ by plants remains in the apoplast and is deposited after water evaporation at the termini of the transpiration stream (Epstein, 1994; Marschner, 1995). Since the trichomes have a large surface area, the translocation and the accumulation of $\mathrm{Si}$ in the hull of Arborio might be enhanced after water evaporation compared with the other cultivars with less or short trichomes.

In the present study, it was indicated that, except for $\mathrm{Ca}$, both of the content and concentration of all the macro elements in the hull decreased until maturity, and this tendency was negatively related to the accumulation of $\mathrm{Si}$ in the hull. Contrary to these decrements, the content of these elements in the brown rice increased with time although the changes in the concentrations were slight except that the concentrations of $\mathrm{K}$ and $\mathrm{Ca}$ decreased at early stage of the grain filling period. These results 
Ansai et al.

suggested that the heavy accumulation of $\mathrm{Si}$ in the hull was the cause of the enhanced accumulation of the other elements in the brown rice. Lu et al. (2013) reported the elemental distribution of $\mathrm{Ca}$ was more in hull (63.8\%) than brown rice $(36.2 \%)$ and this was vice versa for $\mathrm{K}(67.9 \%$ for brown rice). They also showed that the local distribution of $\mathrm{K}$ was highly concentrated in the embryo and $\mathrm{Ca}$ was preferentially

The results of this study indicated that the decreases of the $\mathrm{N}$ and $\mathrm{P}$ contents in the hull and the increase of these elements were most remarkable for Arborio. As mentioned already, the highest content and the concentration of $\mathrm{Si}$ in the hull was observed for this cultivar throughout the grain filling period. Therefore, it was supposed that lower transpiration caused by the heavy accumulation of $\mathrm{Si}$ on the hull enhanced the translocation of the other elements into the brown rice. In addition, the Ca concentration in the hull of Arborio was significantly higher than that of the other cultivars throughout the grain filling period, and that in the brown rice was lower. These results suggest that some of the accumulated Si by Arborio were co-precipitated with $\mathrm{Ca}$ in the hull.

\section{Conclusion}

In summary, the present study indicated that the amount of $\mathrm{Si}$ in the hull of Arborio was higher than that of Tadukan, Nanjing 11 and Nipponbare. The results also suggested that the hull with the high accumulation of $\mathrm{Si}$ might enhance the translocation of other elements such as $\mathrm{N}$ and $\mathrm{P}$ from the hull into the brown rice. Further, the different amounts of deposition of $\mathrm{Si}$ on the abaxial surface of the hull among the cultivars were supposed to be one of the reasons for different weight of the hull in each cultivar. The fact that the hull of the javanica type Arborio showed high $\mathrm{Si}$ content and concentration could be utilized for the production of soil amendments with high $\mathrm{Si}$ contents, and could help to breed high yielding rice cultivars.

\section{Acknowledgements}

The study was carried out under the MEXT (Monbukagakusho) scholarship, Japan. Kochi University, Japan provided the research facilities and Bangladesh Rice Research Institute (BRRI) granted the study leave to conduct the experiment.

\section{References}

Balasta, M. L. F. C., C. M. Perez, B. O. Juliano and C. P. Villareal. 1989. Effects of silica level on some properties of Oryza sativa straw and hull. Can. J. Bot. 67: 2356-2363.

Eneji, A. E., S. Inanaga, S. Muranaka, J. Li, T. Hattori, P. An and W. Tsuji. 2008. Growth and nutrient use in four grasses under drought stress as mediated by silicon fertilizers. J. Plant Nutr. 31: 355-365.

Epstein, E. 1994. The anomaly of silicon in plant biology. Proc. Natl. Acad. Sci. USA, 91: 11-17.

Hasanuzzaman, M., K. Nahar. and M. Fujita. 2014. Silicon and Selenium: Two Vital Trace Elements that Confer Abiotic Stress Tolerance to Plants. Emerging Technologies and Management of Crop Stress Tolerance: Biological Techniques-1, Pp. 377-422

(http://www.sciencedirect.com/science/article/pii/B9780128008768000163) 
Status of Nutrient Elements in Rice Grain in Relation to Silicon Accumulation Pattern During Grain Filling

Hashim, A. B., H. Aminuddin and K. B. Siva. 1996. Nutrient content of rice husk ash of some Malaysian rice varieties. Pertanika J. Trop. Agric. Sci. 19(1): 77-80.

Hodson, M. J. and A. G. Sangstar. 1989. Silica deposition in the inflorescence bracts of wheat (Triticum aestivum). II. X-ray microanalysis and backscattered electron imaging. Can. J. Bot. 67: 281-287.

Hossain, K. A., T. Horiuchi and S. Miyagawa. 1999. Effects of powdered rice chaff application on the $\mathrm{Si}$ and $\mathrm{N}$ absorption, lodging resistance and yield in rice plants (Oryza sativa L.). Plant Prod. Sci. 2: 159-164.

Islam, A. and R. Shaha. 1969. Effects of silicon on the chemical composition of rice plants. Plant Soil. 30: 446-458.

Lu, L., S. Tian, H. Liao, J. Zhang, X. Yang and J. M. Labavitch. 2013. Analysis of metal element distribution in rice (oryza sativa L.) seeds and relocation during germination based on x-ray flourescene imaging of $\mathrm{Zn}$, Fe, K, Ca and Mn. PLOS ONE. 8(2): e57360.

Inanaga, S., Y. Higuchi and N. Chishaki. 2002. Effect of silicon application on reproductive growth of rice plant. Soil Sci. Plant Nutr. 48: 341-345.

Liang, Y. C., T. S. Ma, F. J. Li and Y. J. Feng. 1994. Silicon availability and response of rice and wheat to silicon in calcareous soils. Commun. Soil Sci. Plant Anal. 25: 2285-2297.

Ma, J. F. 2004. Role of silicon in enhancing the resistance of plants to biotic and abiotic stresses. Soil Sci. Plant Nutr. 30: 417-425.

Ma, J. F. and N. Yamaji. 2006. Silicon uptake and accumulation in higher plants. Trends Plant Sci. 11: 392-397.

Ma, J. F., K. Nishimura and E. Takahashi. 1989. Effect of silicon on the growth of rice plant at different growth stages. Soil Sci. Plant Nutr. 35: 347-356.

Mali, M. and N. C. Aery. 2008a. Influence of silicon on growth, relative water contents and uptake of silicon, calcium and potassium in wheat grown in nutrient solution. J. Plant Nutr. 31:1867-1876.

Mali, M. and N. C. Aery. 2008b. Silicon effects on nodule growth, dry matter production, and mineral nutrition of cowpea (Vigna unguiculata). J. Plant Nutr. Soil Sci. 171: 835-840.

Marschner, H. 1995. Silicon. In: Mineral Nutrition of Higher Plants, $2^{\text {nd }}$ edn., Academic press, London, Pp. 417-435.

Mizuno, N. 1987. Effects of silica on hull weight and ripening of rice plants. J. Plant Nutr. 10: 21-59.

Nhan, P. P., N. T. Dong, H. T. Nhan and N. T. M. Chi. 2012. Effect of OryMax ${ }^{\text {SL }}$ and Siliysol $^{\mathrm{MS}}$ on growth and yield of MTL560 Rice. World Appl. Sci. J. 19(5): 704709.

Okuda, A. and E. Takahashi. 1965. The role of silicon. In: The Mineral Nutrition of the Rice Plant, John Hopkins Press, Baltimore, MD, Pp. 126-146.

Savant, N. K., G. H. Snyder and L. E. Datnoff. 1997. Silicon management and sustainable rice production. Adv. Agron. 58: 151-199.

Seo, S. W. and Y. Ota. 1983. Role of hull in the ripening of rice plant. VII. Effect of supplying of silica and potassium during reproductive growth stage on the form 
Ansai et al.

and function of hulls. Nippon Sakumotsu gakkai Kiji. 52: $73-79$ (in Japanese).

Soni, S. L. and D. W. Parry. 1973. Electron probe microanalysis of silicon deposition in the inflorescence bracts of the rice plant (Oryza sativa). Am. J. Bot. 60: 111-116.

Takahashi, E., J. F. Ma and Y. Miyake. 1990. The possibility of silicon as an essential element for higher plant. Comment Agric. Food Chem. 2: 99-122.

Yamauchi, M. and M. D. Winslaw. 1987. Silica reduces disease on upland rice in a high rainfall area. Int. Rice Res. Newslett, 12: 22-23.

Yoshida, S., Y. Ohnishi and K. Kitagishi. 1962. Chemical forms, mobility, and deposition of silicon in rice plant. Soil Sci. Plant Nutr. 8: 15-21. 
Status of Nutrient Elements in Rice Grain in Relation to Silicon Accumulation Pattern During Grain Filling

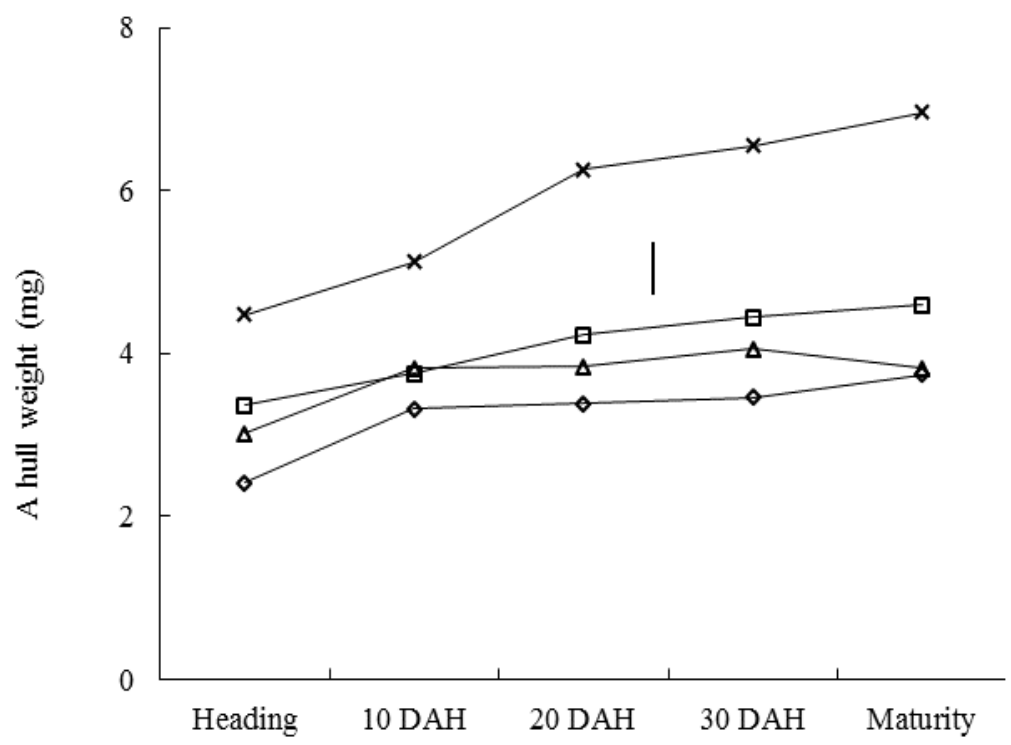

Sampling time

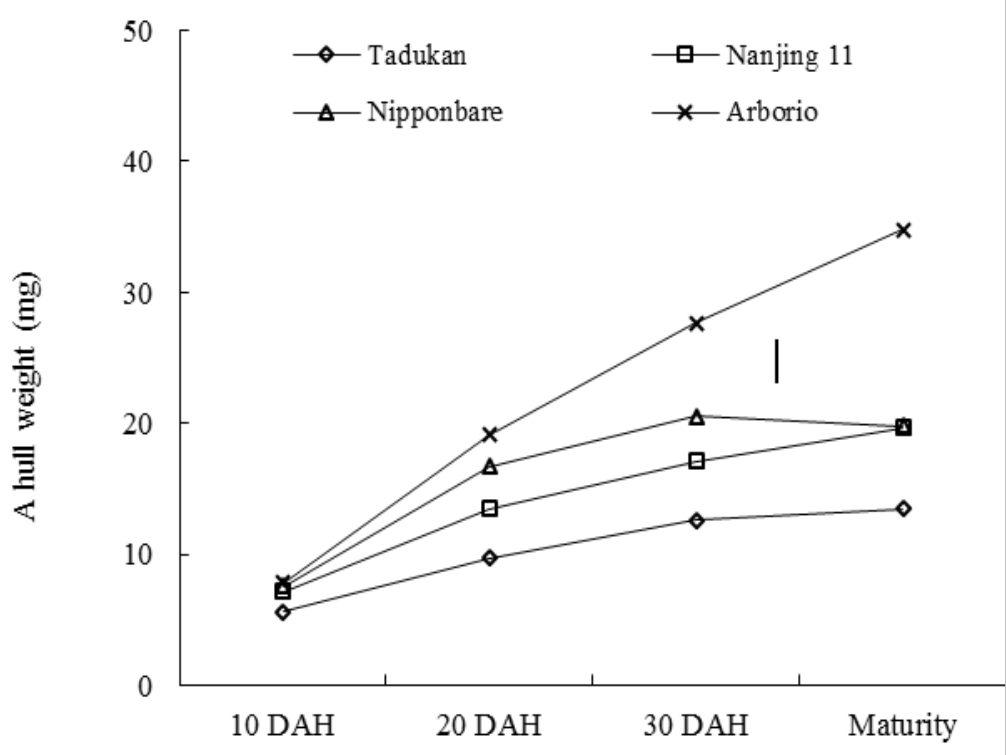

Sampling time

Fig. 1. Dry weight of a hull (A) and a brown rice (B) of different cultivars at different 
Ansai et al.

days after heading (DAH). Bar indicates the LSDvalue for crop-stage $Ч$ variety at $5 \%$.

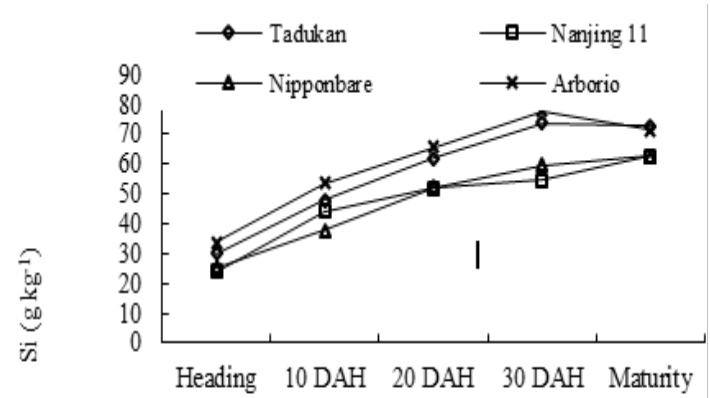

Sampling time

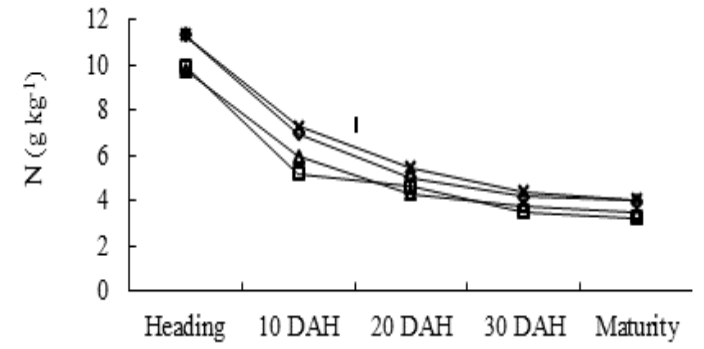

Sampling time

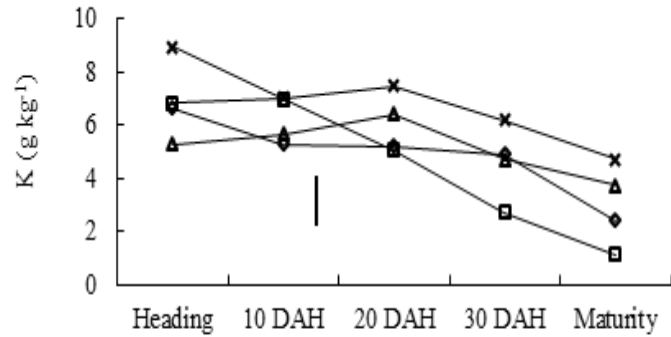

Sampling time

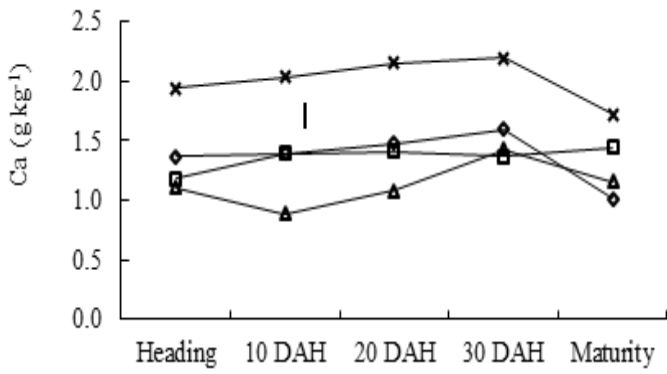

Sampling time
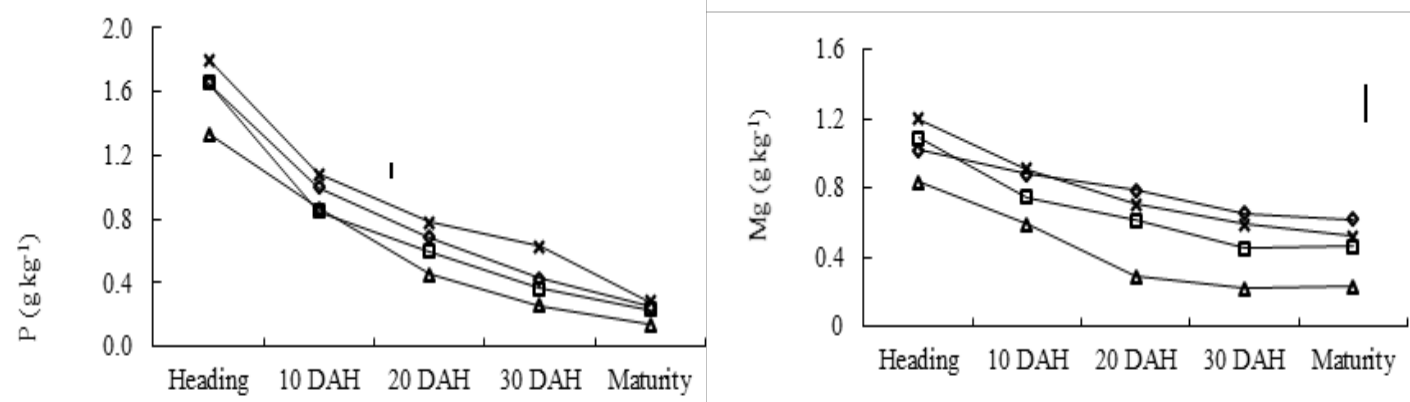

Sampling time 
Status of Nutrient Elements in Rice Grain in Relation to Silicon Accumulation Pattern During

\section{Grain Filling}

Fig 2. Contents of $\mathrm{Si}$ and other elements in the hull of different cultivars during grain filling period. Bar indicates the LSD (0.05) value for crop-stage $\times$ variety. 
Ansai et al.
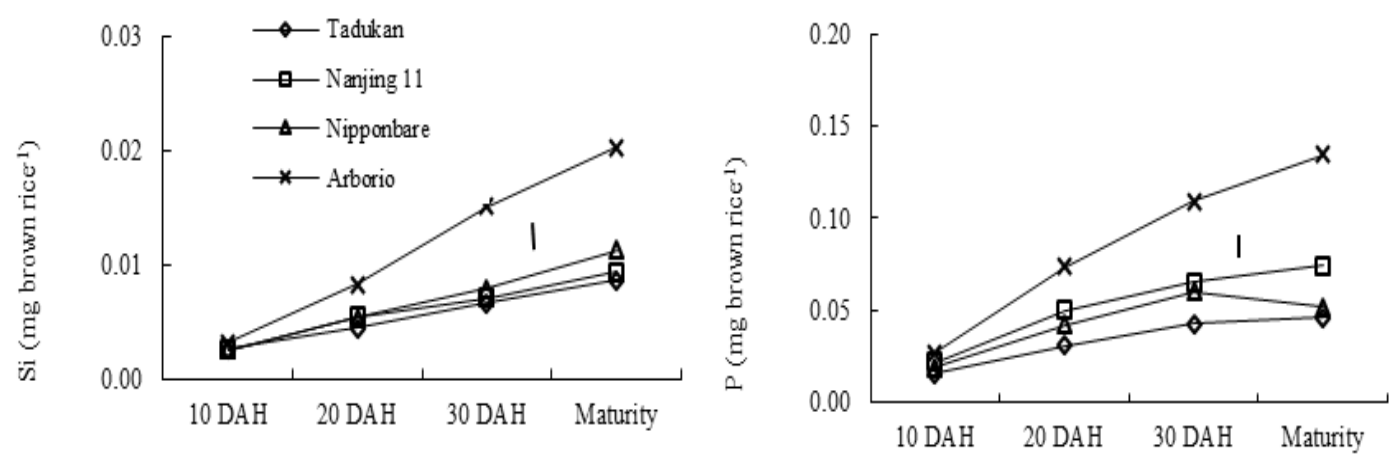

Sampling time
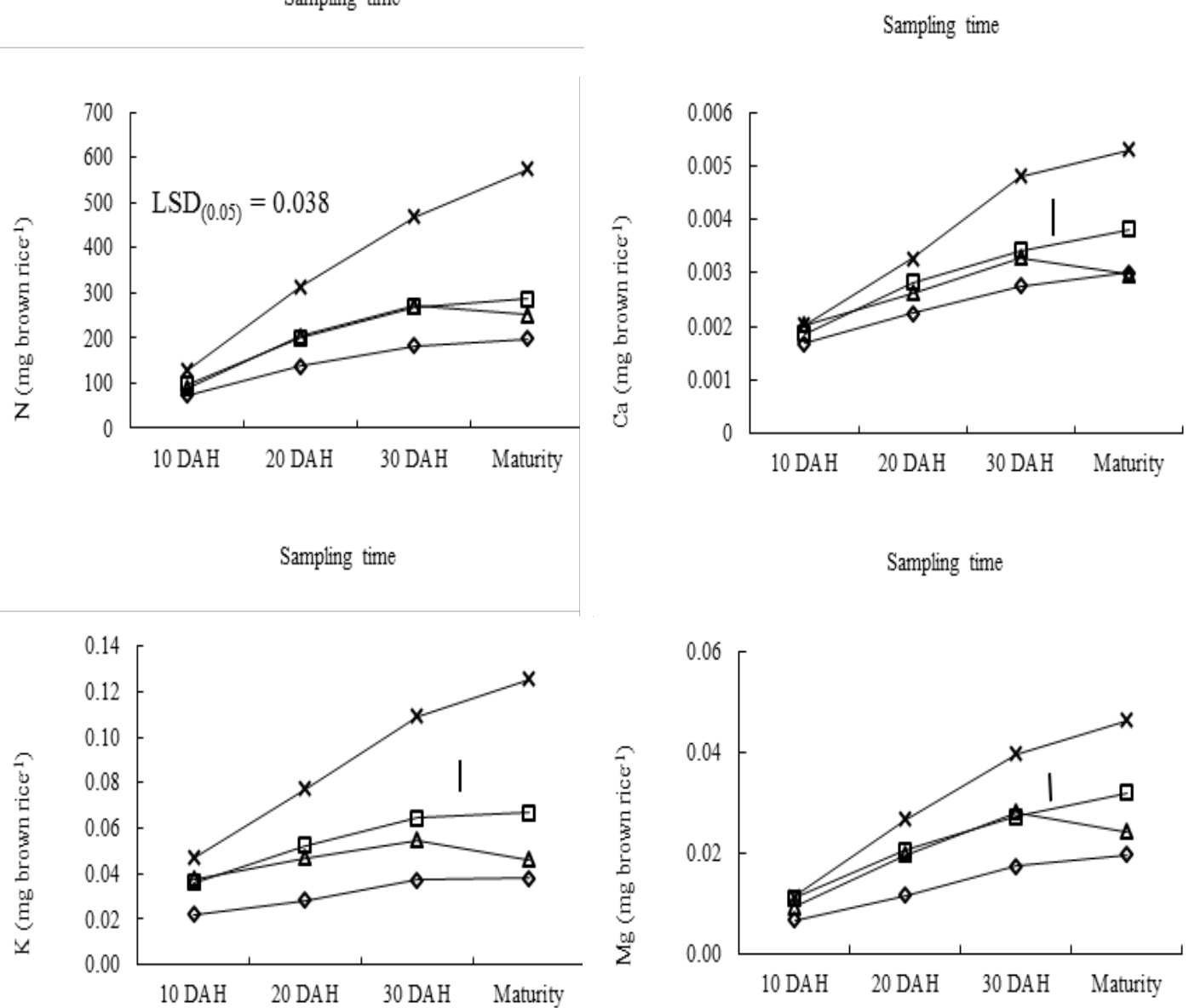

Sampling time

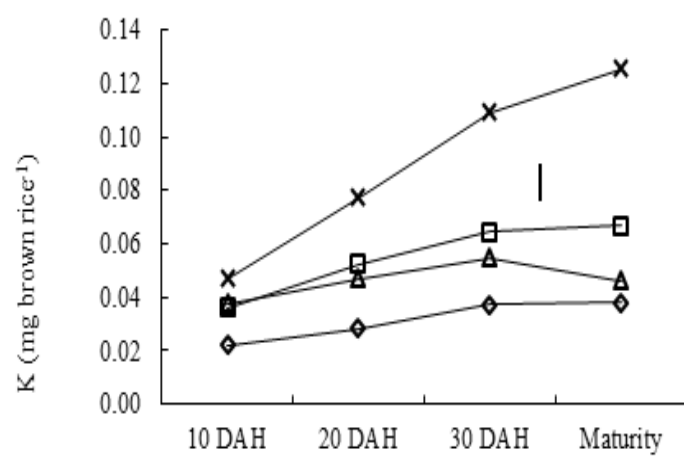

Sampling time

Sampling time

Fig. 3. Contents of $\mathrm{Si}$ and other elements in the brown rice of different cultivars during grain filling period. Bar indicates the $\operatorname{LSD}(0.05)$ value for crop-stage $x$ 
Status of Nutrient Elements in Rice Grain in Relation to Silicon Accumulation Pattern During

\section{Grain Filling}

variety.
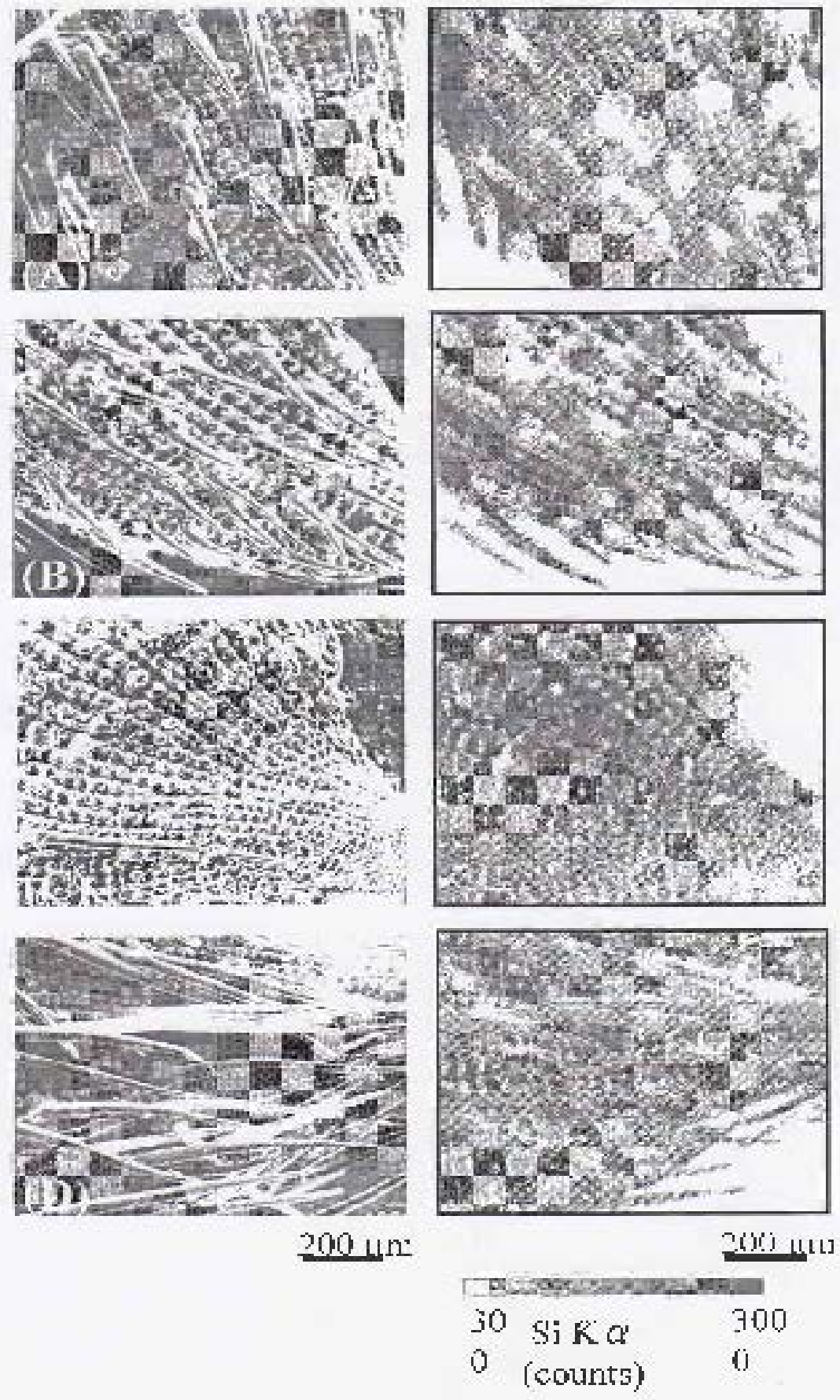

Plate 1. Secondary electron images (left side) and corresponding X-ray distribution of $\mathrm{Si}$ (right side) on the adaxial surface of the hulls (lemma) of different cultivars, 
140

Ansai et al.

$\begin{array}{llll}\text { (A) Tadukan } & \text { (B) Nanjing } 11 & \text { (C) Nipponbare and (D) Arborio. }\end{array}$ 